$£ 15$ 12s. 6d.; Metropolitan (Fore-street, E.C.), £41 13s. 4d. ; Notting Hill (Provident), £26 0s. 10d. ; Paddington (Provident), £41 13s. 4d.; Portland Town (Free), £20 16s. 8d.; Portobello-road (Provident), $£ 5$ 4s. 2d.; Public, Stanhope-street, W.'C., £57 5s. 10d.; Queen Adeclose, E.C., £57 5 ss. 10d.; ' Royal Maternity Charity, Finsbury-square E.C., £125; Royal Pimlico (Provident), £52 1s. 8d.; ; Royal South London, St. George's-circus, S.E., £62 10s.; SS. George's and James's King's-street, W., $£ 67$ 14s. 2d. ; 'St. George's, Hanover-square (Provident), £52 1s. 8d.; St. John's Wood (Provident), $£ 23$ 19s. 2d. . St.

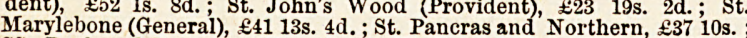
Marylebone (General), £41 13s. 4d.; St. Pancras and Northern, £37 10s. Lambeth, £57 5s. 10d.; ; South London Medical Aid Institute, Waterloobridge-road, S.E., £31 5s.; ; stamford-hill, \&c., Stoke Newington, N., $£ 54$ 3s. 4d.; Tower Hamlets, Stepney, E., £46 17s. 6d.; Wandsworth Common (Provident), £10 8s. 4d.; Westbourne (Provident), £20 16s. 8d. West Dulwich (Provident), £7 5s. 10d.; Western, Rochester-row, Westminster, S.W., £46 17s. 6d.; Western General, Marylebone-road, S.W., $£ 1358$ s. 4d.; West Ham and Stratford, E., $£ 62$ 10s. ; Westminste

\section{IN a Hospital.}

"Miserere mihi Domine et exaudi orationem meum."

Look in pity on Thy children,

Sick and sorrowful are we :

Thou who once didst heal the leper,

Miserere Domine.

Sad our lives, and often dreary,

Sickness on all sides we see ;

Jesus, who didst heal the leper,

Miserere Domine.

Thou alone canst heal our weakness,

All our pains are known to Thee

Jesus, who didst heal the leper, Miserere Domine.

Teach us how to bear our burdens,

Till Thy mercy sets us free;

Jesus, who didst heal the leper,

Miserere Domine.

May Thy mercy cure us wholly,

But if, Lord, that may not be,

Still in death, as in our sickness, Miserere Domine.

\section{AMUSEMENTS AND RELAXATION.}

\section{Second Quarterly Word Competition Commenced July 6th, ends September 28th.}

Three Prizes of $15 \mathrm{~s}$., $10 \mathrm{~s}$., $5 \mathrm{~s}$, , will be given for the largest number of words derived from the words set for dissection.

Proper names, abbreviations, foreign words, words of less than four letters, and repetitions are barred; plurals, and past and present participles of verbs, are allowed. Nuttall's Standard dictionary only to be

N.B.-Word dissections must be sent in WEEKLY, arranged alpha. betically, with correct total affixed.

The word for dissection for this, the Fifth week of the quarter, being "O S B O R N E."

\section{Results of Third Week.}

\begin{tabular}{|c|c|c|c|c|c|}
\hline Names. & 25 th & Totals. & Names. & $25 \mathrm{t}$ & Totals. \\
\hline (a) & 47 & .. 237 & Rover & & 165 \\
\hline importe Q & 45 & 209 & Leirion ... & & \\
\hline amps........... & - & .. & Matron & 45 & 132 \\
\hline nie $\ldots$. & - & 186 & F. C. J. & 43 & 163 \\
\hline Patience........ & 46 & 227 & Percy Verance. & & 18 \\
\hline micus & 42 & 225 & Gleniffer......... & 46 & 175 \\
\hline roxbourne & 47 & .. 230 & Gypsye & 40 & 197 \\
\hline dwe & 46 & . $\quad 216$ & Ladyr. & 27 & 127 \\
\hline er & 47 & 221 & A. B. & 41 & 170 \\
\hline Lightowlers & 47 & .. & Essie & 45 & 178 \\
\hline Lauriston . & 47 & .. 227 & W. G. R.. & 37 & 180 \\
\hline Rattler & $\bar{z}$ & .. & Cowboy Bill & 46 & 179 \\
\hline Paignton & 47 & 179 & M. L. A. . & 30 & 117 \\
\hline Fassifern & - & .. & Little Tuppy..... & 33 & 110 \\
\hline W. R. E... & 48 & 227 & Embryo & & 56 \\
\hline Espe & 49 & 229 & K. Jarm & - & 43 \\
\hline M. & 48 & 234 & Reveal. & 47 & 196 \\
\hline Isabel . & 47 & 215 & Jenny Wren .... & 32 & 163 \\
\hline Buxton & 28 & 150 & Condorcet & 38 & 194 \\
\hline Nux Vom & 46 & .. & Electrician. & 27 & 27 \\
\hline Qu'appelle & 48 & 206 & Pearl & 38 & 38 \\
\hline 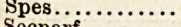 & $\overline{1}$ & .. & R. W. & 43 & 43 \\
\hline aar & 47 & 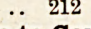 & Nurse Amie .... & 一 & \\
\hline
\end{tabular}

N.B.-All letters referring to this page which do not arrive at 139 and 140, Salisbury-court, London, E.C., by the first post on Thursdays, and are not addressed PRIZE EDITOR, will in future be disqualified and

Competitors can enter for all quarterly competitions, but no com. petitor may take more than two quarterly prizes during the year.

\section{SCRAPS AND GLEANINGS.}

THERE is an outbreak of measles at Coventry.

A HOSPITAL for birds is the latest institution opened in Chicago.

DEVONPORT HOSPITAL SATURDAY FUND this year nearly reaches $£ 100$. WILlias BRIXToN died last week at St. Mary's Hospital from hydrophobia.

CANON FARRAR preached last Sunday in aid of the seaside camp for London boys.

THE mortality amongst illegitimate children boarded out in France is from 35 to 40 per cent.

THE Prince of Wales dined with the Stewards of St. Bartholomew's Hospital on July 24 th.

THE Earl Percy will open the Victoria Jubilee Infirmary, at Tynemouth, on August 3rd.

ON August 12th an examination will be held for eight commissions in the army medical staff.

THE City Corporation have voted fifty guineas to the Children's Country Holiday Fund.

Mr. William ANDERSON will deliver the opening address at St. Thomas's on October 1st.

DR. CYRIL JECKS has been appointed resident medical officer to niversity College Hospital.

Cardinal Manning lately opened St. Veronica's Retreat in Chiswick, a home for female inebriates.

IT is proposed to celebrate the Queen's visit to Wales by the erection of a hospital to bear her name.

DR. SIDNEY COUPLAND is preparing for the press the last work of the late Wilson Fox-"Diseases of the Lungs."

MURRAY's MAgazine for August contains an article by Mr. William Covington- "Is Hospital Sunday a Failure?"

THE tableaux vivants at Shrewsbury, to raise funds to supply new beds to Salop Infirmary, were a great success.

THe Duchess of Albany visited the Princess Alice Memorial Hospital on July 19th, and took tea in the matron's room.

THE Marchioness of Dufferin will publish a selection from her Indian journals under the title of " Our Viceregal Life in India."

Mr. VAN PRAAGH has been presented with a silver salver by the committee of the Central London Throat and Ear Hospital.

THE subscription list for Halifax New Infirmary now reaches $£ 49,426$. The matron of the Borough Hospital has given two guineas.

A BAzAAR was held at Knightsbridge last Saturday in aid of Lady Sandhurst's Cripples Home, and the Hutton Home, Sunbury.

SIR FREDFRICK ABEL, the well-known chemist, will be the president of the meeting of the British Association next year at Leeds.

THk other day a cricket match between the doctors and lawyers was played at Sunderland, and the proceeds given to the Infirmary.

THE Queen proposes, it is said, to visit Strathpeffer in the autumn, for the purpose of taking a course of the baths for which that place is

A FATAL case of "local" cholera is reported from a place near Buda. pest, and four relatives of the deceased are said to be suffering from the malady.

SURGEON KEATINGE is in charge of a floating hospital, consisting of five dahabiehs, whir

THE bazaar recently held by Mrs. Arfwedson was the means of benefit. ing the funds of the Samaritan Hospital to the extent of $£ 80$, that ing the funds of the Samaritan
amount being the net proceeds.

AT Corbeil a cat went mad and bit several other tabbies, then the villagers decreed and executed the death of all the cats in the neighbour hood. Oh, to be a mouse at Corbeil !

MRS. PEEL's "At Home," in aid of the Children's Country Holiday's Fund, was very successful. She has been able to transmit to the treasurer, the Hon Alfred Lyttelton, over $£ 160$.

THE Rev. Astley Cooper has sent the sum of $£ 14$ 13s. 5d. to Mrs. Jeune towards her fund for giving poor and sickly London children a holiday
in the country. The amount was collected in the Hickey's Almshouse.

THE Lord Mayor has received from the Delegate Chief Rabbi (Kev. Dr. H. Adler) a cheque for $£ 65715$ s. 8d., being the amount subscribed by the various Jewish congregations in London for the Hospital Sunday Fund.

THE Medical Officer of Health for Kensington, in his latest report, writes feelingly of the nuisance from brick-burning in the outlying part of London. The odour from the brickfields is insupportable, especially at night.

At the Wicklow Assizes, Mrs. Bright, until recently matron of Armagh Lunatic Asylum, was awarded $£ 700$ damages against th Northern Railway Company for injuries received in the Armagh railway disaster.

DR. OLIVIER, of Havre, advises people to be careful in drinking cider. It is made, as a rule, with stagnant water, the microbes in which do not perish during fermentation. On the contrary, the fever germs thrive upon the juice of the apple.

DR. ANNA BAYER, of Berne, has received a memorial from thirty Women's Societies in Bohemia and Moldavia, begging her to devote he talents to her native country. The Austrian law, however, forbids a woman to practice medicine.

THE committee of "The Gordon Boy's Home" made their annual inspection of the home and its inmates on August 1, when the replica of the picture of General Gordon, entitled, "The Last Watch" was presented by the artist, Mr. Lowes Dickenson, to the institution.

AT St. Michael's, Folkestone, the other day, the Rev. E. Husband, in announcing a "flower service" in the afternoon for the benefit of the workhouse, invited his congregation to bring, not only flowers and fruit for the children, but also offerings of tea for the old women, and tobacco for the old men. 